\title{
IS PEACEKEEPER'S STRESS SYNDROME REAL? A CROSS-SECTIONAL STUDY OF SOLDIERS AT UN MISSION
}

\author{
Nazia Mustafa, Fahad Haleem, Hina Iqbal*, Najm Us Saqib Khan**, Umair Ali***, Zakir Hussain**** \\ General Headquarter, Rawalpindi Pakistan, ${ }^{*}$ Islmia College, Peshawar Pakistan, ${ }^{* *}$ Naval Headquarter Islamabad Pakistan, ${ }^{* * *}$ Armed Forces Institute of \\ Radiology \& Imaging/National University of Medical Sciences (NUMS) Rawalpindi Pakistan, ${ }^{* * * *}$ Quetta Institute of Medical Sciences, Quetta
}

\begin{abstract}
Objective: To study the Peacekeeping Stress syndrome and see its relationship with various demographic variables (age, years of service and marital status).

Study Design: Cross sectional study.

Place and Duration of Study: Study was carried out on Pakistani Peacekeepers who were deployed in Democratic Republic of Congo in Jun 2019.

Methodology: About 536 Pakistani male peacekeepers with mean age of 33 years, deployed in Democratic Republic of Congo were taken as study sample. By group testing method, all participants were assessed through Depression, Anxiety and Stress Scale (DASS-21), Urdu version and demographic form consisted of age, marital status, education, years of service and rank.

Results: Results revealed that DASS-21 has good reliability $(\mathrm{a}=0.71)$ for the present sample and prevalence of depression, anxiety and stress among Pakistani peacekeepers was low $(2.9 \%, 4 \%$ and $4 \%$ respectively). Further to it, there was significant negative correlation of depression and stress with the age and years of service whereas relationship of anxiety with these variables (age and years of service) was non-significant. There were significant mean differences between the married and unmarried peacekeepers on Anxiety and Stress and non-significant on depression.

Conclusion: Present study provided useful information regarding the mental health of peacekeepers and highlighted the fact that Pakistani peacekeepers are resilient enough to handle the challenges of international environment.
\end{abstract}

Keywords: Anxiety, Depression, Peacekeeping stress syndrome, Stress.

This is an Open Access article distributed under the terms of the Creative Commons Attribution License (http://creativecommons.org/licenses/by/4.0), which permits unrestricted use, distribution, and reproduction in any medium, provided the original work is properly cited.

\section{INTRODUCTION}

Combat stress and the mental health of military personnel have been widely studied andreported in the international research. However, research specially devoted to the mental health of peacekeepers is relatively ignored in the military mental health literature ${ }^{1-3}$. Peacekeeping is a phenomenon in which military intervention in a conflicted area, authorized by the UN Security Council has been carried out from multiple troops contributing countries according to UN mandate ${ }^{4}$. These UN missions involve overseas deployment, hostile and harsh conditions, numerous stressful and potentially traumatic events (PTEs), armed conflicts, disregard on part of somelocal parties for peacekeepers' security and operating under restrictive rules of engagement which can lead to role conflict ${ }^{5}$.

All these risk factors make peacekeepers vulnerable for development of stress and other psychiatric problems. This peacekeeping stress is also known as peacekeeping stress syndrome, a condition in which peacekeepers find themselves unable to respond to atrocities and violence due to strict ROE. This syndrome is characterized by rage, frustration, feelings of impor-

Correspondence: Dr Nazia Mustafa, Block No. 1, Flat No. 2, 206 Tufail Road, Rawalpindi Pakistan

Received: 13 Jan 2021; revised received: 16 Feb 2021; accepted: 17 Feb 2021 tence, and helplessness. Though, it is not observed frequently as Peacekeeping operations have the potential to offer opportunities for growth and resilience and at the same time, a soldiertrained for conventional military operations, is obliged to participate in the unconventional operations of waging peace in alien lands often in violent situations. In the process, he gets exposed to widely variable demands for adjustments that have the potential to bring many maladaptive responses to the fore ${ }^{6}$.

Bartone PT12 has identified five dimensions of psychological stress for peacekeepers during deployment which includes isolation (separation from home and family), ambiguity (role confusion), powerlessness (compassion fatigue and secondary traumatic stress), boredom (repetitive, monotonous routine and lack of recreations) and threat/danger (attack by civilians, local troops, and the risk of spread of infectious diseases). These dimensions are incredibly important factors which significantly contribute to the development of stress amongst peacekeepers 7 .

Several studies have been carried out, throughout the world, to study the various aspects of peacekeeping stress. About 1025 Australian peacekeepers were studied to see the mental health impacts of peacekeeping deployments and it was revealed that Peace- 
keepers had significantly higher prevalence of posttraumatic stress disorder (16.8\%), major depressive episode $(7 \%)$, generalized anxiety disorder $(4.7 \%)$, alcohol misuse $(12 \%)$, alcohol dependence $(11.3 \%)$ and suicidal ideation $(10.7 \%)$ when compared with the civilian population. The presence of these psychiatric disorders was most strongly and consistently associated with exposure to potentially traumatic events (PTEs.) ${ }^{3}$. Another study has been conducted on socio-demographic profile and mental morbidity in 37507 Indian soldiers repatriated from UN Peacekeeping mission during the study period 2011 to 2015. Results showed that incidence of mental illness per year, during UN stay, was between 0.34 to 0.87 . Amongst psychiatric morbidity, major depression was observed in $26 \%$, substance use disorder in $17.4 \%$, panic disorder and mixed anxiety disorder was diagnosed in $13 \%$ each. There were no cases of Post-Traumatic Stress Disorder (PTSD) and attempted suicide among these soldiers ${ }^{5}$.

The mental health of Chinese peacekeepers ( $n=$ 440) under the influence of stressful and traumatic events in Liberia was studied and results indicated high rates of depression and interpersonal sensitivity of Chinese peacekeepers than the Chinese military $(p<0.01)$. These factors of the peacekeepers positively correlated with the age, military service duration, years of education and military rank ${ }^{8,9}$. In Pakistan, there is Scarcity of literature on psychological stress and mental health issues in peacekeepers, despite many years of participation in United Nations (UN) Peacekeeping missions. Only few studies have been conducted in this area.

To identify the Psychiatric morbidity among Pakistani peacekeepers (172), a study has been carried out in the United Nations Peace Keeping Mission in Liberia from December 2007 to December 2008. Findings suggested that about $5(25 \%)$ were having mild episodes of depression somatic features, $9(50 \%)$ were having Anxiety problems and about 5 (25\%) had emotional and behavioral issues associated with use of Mefoloquine $^{10}$. Therefore, present study is designed to assess the impacts of peacekeeping conditions on mental health of Pakistani soldiers deployed in Democratic Republic of Congo.

\section{METHODOLOGY}

In the present study, a cross sectional study designed was used was carried and data of 536 Pakistani peacekeepers who were deployed in Democratic Republic of Congowas collected in June 2019 through convenient purposive sampling. Before the start of study, Ethical Approval was sought from the Psychological Research Wing of PA Dte, GHQ and study purpose was discussed with commanding officer to secured the permission. After that, a short-info care session was given to all the participants with the aim of explaining the purpose of the study and asking for their consent.

After obtaining their verbal consent. By group testing method, all participants were assessed through Depression, Anxiety and Stress Scale (DASS-21), Urdu version and demographic form consisted on age, marital status, education, years of service and rank. DASS21 is aset of three self-report scales designed to measure the emotional states of depression, anxiety and stress ${ }^{11}$. Participants who didn't give consent, who had any type of physical or mental disease and history of any traumatic event or surgery in past 6 months were excluded from the study.

They were asked to read each statement carefully and give their responses by selecting the response category which they considered appropriate. They were acknowledged for their participation and cooperation.

The data was entered on SPSS-24 and analyzed. Descriptive statistics were carried out to describe the mean, SD, frequencies, and reliability coefficients. Further inferential statistics involved Pearson Correlation, used to see the relationship between different variables and $t$-test to compare the mean differences of various groups.

\section{RESULTS}

Results revealed that age of participants was between 20-56 years $(\mathrm{M}=33.31, \mathrm{SD}=5.35)$ and among them 66 were unmarried and 470 were married. It was further shown that depression, anxiety and stress scale (DASS-21) was reliable $(\alpha=0.71)$.

Table-I: Descriptive statistics of variables $(n=536)$.

\begin{tabular}{l|c|c}
\hline Variables & Mean & SD \\
\hline Age & 33.31 & 5.35 \\
\hline Years of Service & 13.86 & 5.08 \\
\hline Depression (D) & 1.62 & 2.52 \\
\hline Anxiety (A) & 0.99 & 2.2 \\
\hline Stress (S) & 1.62 & 3.6 \\
\hline
\end{tabular}

Table-III shows the correlation coefficients of various aspects of depression, anxiety, stress and general psychological distress with age and years of service of Peacekeepers. Results revealed that depression and stress were significantly negatively correlated with the age andyears of service of the peacekeepers whereas 
relationship of anxiety with these variables (age and years of service) was non-significant.

Table-II: Frequencies and percentages of depression, anxiety and stress among pakistani peacekeepers $(n=536)$.

\begin{tabular}{l|c}
\hline Symptoms & n (\%) \\
\hline Depression (D) & $16(2.9)$ \\
\hline Anxiety (A) & $24(4)$ \\
\hline Stress (S) & $24(4)$ \\
\hline
\end{tabular}

Table-III: Correlation coefficients of various aspects of depression, anxiety and stress with age and years of service of peacekeepers $(n=536)$.

\begin{tabular}{l|c|c|c|c|c}
\hline Variables & $\mathbf{1}$ & $\mathbf{2}$ & $\mathbf{3}$ & $\mathbf{4}$ & $\mathbf{5}$ \\
\hline Depression & - & - & - & $-.86^{*}$ & $-.097^{*}$ \\
\hline Anxiety & & - & - & -.062 & -.058 \\
\hline Stress & & & & $-.87^{*}$ & $-.86^{*}$ \\
\hline age & & & & & $.91^{* *}$ \\
\hline Service & & & & & - \\
\hline${ }^{*} p<.05,{ }^{*} p<.05$ & \multicolumn{5}{l}{}
\end{tabular}

Table-IV indicates the mean differences of married and unmarried peacekeepers on depression, anxiety and stress. Results indicate that there were significant mean differences between the married and unmarried peacekeepers on Anxiety and Stress as unmarried individuals experience more anxiety and stress as compared to married onesbut non-significant on depression. sonnel $3,8,14$. Results of present study revealed that only 2.9\% Pakistani peacekeepers experienced depression whereas prevalence for anxiety $(4 \%)$ and stress $(4 \%)$ was also quite low as compared to other countries. This low prevalence of mental health issues among Pakistani peacekeepers in our study can be explained by the fact that this study was carried out in a lowintensity conflict area where the Pakistani troops did not engage in active fighting. Probably that was the reason they did not experience significant psychological problems ${ }^{15}$.

Moreover, it is considered the Pakistani military has become well prepared to conduct peacekeeping and peace enforcement operations, including preparing, educating, and supporting soldiers with respect to these unique demand and roles that is why they didn't find it difficult to work in UN environment ${ }^{16,13}$. These findings highlighted the fact that Pakistani peacekeepers are resilient enough to handle the stresses of international environment. Studies on Canadian military personnel showed similar types of findings as their mental health-related negative outcomes were quite low ${ }^{4,17}$.

Further to this, Perception of deployment plays significant role in the management of stress among

Table-IV: Mean differences of married and unmarried peacekeepers on depression, anxiety and stress ( $\mathrm{n}=536$ ).

\begin{tabular}{|c|c|c|c|c|c|c|c|}
\hline \multirow{2}{*}{ Variables } & \multirow{2}{*}{$\begin{array}{c}\text { Married }(n=470) \\
\text { Mean } \pm \text { SD }\end{array}$} & \multirow{2}{*}{$\begin{array}{c}\text { Unmarried }(n=66) \\
\text { Mean } \pm \text { SD }\end{array}$} & \multirow{2}{*}{$\mathbf{t}$} & \multirow[b]{2}{*}{$p$} & \multicolumn{2}{|c|}{$95 \% \mathrm{CI}$} & \multirow{2}{*}{ Cohen's d } \\
\hline & & & & & LL & UL & \\
\hline Depression & $1.57 \pm 2.44$ & $1.98 \pm 3.03$ & 1.25 & 0.209 & 1.06 & 0.235 & 0.14 \\
\hline Anxiety & $0.90 \pm 2.13$ & $1.59 \pm 3.08$ & 2.29 & 0.022 & 1.27 & 0.099 & 0.25 \\
\hline Stress & $1.49 \pm 3.42$ & $2.59 \pm 5.02$ & 2.30 & 0.022 & 2.04 & 0.162 & 0.25 \\
\hline
\end{tabular}

\section{DISCUSSION}

United Nations Peacekeeping operations frequently exposed individuals to a great variety of stressors which effects their mental health in a number of ways, like making them vulnerable for stress and providing them opportunities for resilience and growth. Past studies have had inconsistent results regarding whether or not their deployment experience affects their mental health outcomes,12,13. High prevalence of post-traumatic stress disorder $(16.8 \%)$, major depressive episode $(7 \%)$, generalized anxiety disorder $(4.7 \%)$, alcohol misuse $(12 \%)$, alcohol dependence $(11.3 \%)$ and suicidal ideation (10.7\%) were shown among australian peacekeepers. Similarly, major depression was observed $26 \%$, substance use disorder was $17.4 \%$, panic disorder and mixed anxiety disorder was 13\% among Indian soldiers 3,5 . Psychological effects of peacekeeping duties on mental health were also quite high among New Zealand, Chinese and Australian Defense Force per- peacekeepers ${ }^{18}$. And it was found in our study that Pakistani peacekeepers mostly have positive perception of deployment (83\%) which includes financial advantage and professional grooming. Lack of recreational facilities, separation from family and risk of getting infectious disease are their negative perceptions. It was observed that married personnel have more negative perception of the deployment $(70 \%$ vs. 54\%) 10 than singles.

Many other factors contributed to the development of mental health issues among peacekeepers such as age, military service duration, years of education and military ranks ${ }^{8,19}$. So another objective of the present study was to see the relationship of peacekeeping stress with various demographic variables such as age, years of service and marital status. Results revealed that depression and stress were negatively correlated to age and years of service of the Pakistani peacekeepers whereas relationship with anxiety was not sig- 
nificant. Further to it, there were significant differences among married and unmarried peacekeepers were observed on anxiety and stress as unmarried individuals experience more anxiety and stress as compared to married onesbut not on depression. Past researches also showed that socio-demographic variables were significant factors affecting the level of stress among peacekeepers 20,21 . For example, younger age groups (20-30 years) having service tenure of $<10$ years suffer highest from stress in their lives ${ }^{22}$. Actually, with increasing age and service, individuals become more mature and develop coping mechanisms which help them manage their stress in a better way.

\section{CONCLUSION}

Present study provided useful information regarding the mental health of peacekeepers and highlighted the fact that Pakistani peacekeepers are resilient enough to handle the challenges of international environment. It also emphasized on addressing this issue in current and future research by conducted long term follow-up studies to see the impact of overseas deployment on soldiersin detail.

\section{CONFLICT OF INTEREST}

This study has no conflict of interest to be declared by any author.

\section{REFERENCES}

1. Loscalzo Y, Giannini M, Gori A, Fabio AD. The wellbeing of Italian peacekeeper military: Psychological resources, quality of life and internalizing symptoms. Front Psychol 2018; 9(1): 103.

2. Jenne N, Bisshopp FU. Female Peacekeepers: UNSC Resolution 1325 and the Persistence of Gender Stereotypes in the Chilean Armed Forces. Int Peacekeep 2021; 28 (1): 134-59.

3. Forbes D, O'Donnell M, Brand RM, Korn S, Creamer M, McFarlane AC, et al. The long-term mental health impact of peacekeeping: prevalence and predictors of psychiatric disorder. B J Psych open 2016; 2(1): 32-37.

4. Sareen J, Stein MB, Thoresen S, Belik SL, Zamorski M, Asumundson GJG, et al. Is peacekeeping peaceful? A systematic review. Can J Psychiatry 2010; 55: 464-72.

5. Dixit S, Chauhan VS, Bhattacharyya D. Are Indian Peacekeepers on Path to Mental Peace? J Clin Diagn Res 2018; 12(12): VC01VC05.

6. Shigemura J, Nagamine M, Harada N, Tanichi M, Shimizu K, Yoshino A. Peacekeepers deserve more mental health research and care. BJ Psych Open 2016; 2(2): e3-e4.

7. Bartone PT, Adler AB. A Model of Psychological Stress in Peacekeeping Operations. Army Medical Research Unit Europe (USAMRU-E). Mil Med 1995 Jul 13. Available from: DOI: 163. 14. 10.1093/milmed/163.9.587.

8. Sun XY, Zhao L, Chen CX, Cui XL, Guo J, Zhang LY. Mental health of Chinese peacekeepers in Liberia. Eur J Psychiat 2014; 28(2): 77-85.

9. Berg A, Bjarnegård E. Dissecting gender imbalance: a horizontal perspective on when risk matters for the assignment of women to UN peacekeeping missions. Res Militaris 2016; 2(2): 1-14.

10. Ahmed MN, Sajid WB, Zaubi M, Sabih F. Psychiatric morbidity in Pakistani peacekeepers and their perception about deployment in Liberia. Pak Armed Forces Med J 2010; 60(2): 204-08.

11. Aslam N, Kamal A. Translation, validation and effectiveness of depression, anxiety and stress scale (DASS-21) in assessing the psychological distress among flood affected individuals. JPPS. 2020; 17(3): 16.

12. Gray MJ, Bolton EE, Litz BT. A longitudinal analysis of PTSD symptom course: delayed-onset PTSD in Somalia peacekeepers. J Consult Clin Psychol 2004; 72(5): 909.

13. Shigemura J, Nagamine M, Harada N, Tanichi M, Shimizu K, Yoshino A. Peacekeepers deserve more mental health research and care. B J Psych 2016; 2(2): e3-e4.

14. Macdonald C, Chamberlain K, Long N, Mirfin K. Stress and mental health status associated with peacekeeping duty for New Zealand defence force personnel. Stress Med 1999; 15(4): 235-41.

15. Zamorski MA, Rusu C, Garber BG. Prevalence and correlates of mental health problems in Canadian Forces personnel who deployed in support of the mission in Afghanistan: findings from post-deployment screenings. Can J Psychiatr 2014; 59(6): 319-26.

16. Wright B, Forbes A, Kelsall H, Clarke D, Ikin J, Sim M. 'Post-deployment appraisal' and the relationship with stress and psychological health in Australian veterans. Soc Psychiatry Psychiatr Epidemiol 2015; 50(12): 1885-92.

17. Sareen J, Stein MB, Thoresen S, Belik SL, Zamorski M, Asmundson GJ. Is peacekeeping peaceful? A systematic review. J Psychiatr 2010; 55(7): 464-72.

18. Lundin T, Otto U. Swedish UN soldiers in Cyprus, UNFICYP: Their psychological and social situation. Psychother Psychosomat 1992; 57(4): 187-93.

19. Boulos D, Fikretoglu D. Influence of military component and deployment-related experiences on mental disorders among Canadian military personnel who deployed to Afghanistan: a cross-sectional survey. BMJ Open 2018; 8(3): e018735.

20. Tobin J. Occupational stress and UN peacekeepers. Ir J Psychol Med 2016; 32: 205-08.

21. Bhadra ST. Prevalence and Factors Affecting the Stress among Nepalese Peacekeepers. hesis for: Masters Degree in Crisis Management Studies. 2020; Available at: 10.13140/RG.2.2.16807.16809.

22. Sharma S. Do Demographic variables affect the stress levels of indian soldiers? Vision 2015; 19(4): 324-35. 